\title{
Sprawozdanie z działalności Międzywydziałowej Katedry Teologii Katolickiej Uniwersytetu w Białymstoku w roku akademickim 2010/2011
}

Ponieważ w prezentowanym tomie „Rocznika Teologii Katolickiej” opublikowano dwa sprawozdania z działalności Katedry Teologii Katolickiej: jedno zaległe za rok akademicki 2009/2010 i niniejsze, prezentujące dokonania MKTK w roku akademickim 2010/2011, ich Autor, by uniknąć powtórzeń, zdecydował się w poniższym tekście odejść od formy narracyjnej przekazu na rzecz ujęcia statystycznego, jako bardziej przejrzystego.

\section{Działalność dydaktyczna}

W roku sprawozdawczym wykłady na UwB prowadzili:

- ks. prof. dr hab. Józef Zabielski: „Bioetyka” na Wydziale Biologiczno-Chemicznym, „Etyka”, „Współczesne koncepcje filozofii i etyki” i seminarium magisterskie na Wydziale Pedagogiki i Psychologii;

- ks. dr hab. Adam Skreczko prof. UKSW i UwB: seminarium magisterskie na Wydziale Pedagogiki i Psychologii;

- ks. dr Tadeusz Kasabuła: „Chrześcijańskie dziedzictwo Europy” na Wydziale Historyczno-Socjologicznym, „Elementy przedchrześcijańskie w religijności pogranicza polsko-litewsko-ruskiego w XVI-XVIII wieku" na Wydziale Filologicznym - w Instytucie Filologii Polskiej i w Katedrze Neofilologii;

- ks. dr Andrzej Proniewski: „Teologiczne uwarunkowania komunikacji interpersonalnej”, „Tajemnice wszechświata. Dialog wiary z nauką” na Wydziale Biologiczno-Chemicznym, „Etyka zawodowa”, „Współczesne koncepcje filozofii i etyki" oraz seminarium magisterskie na Wydziale Pedagogiki i Psychologii;

- Katedra Teologii Katolickiej w roku akademickim 2010/2011 ukończyła dwa semestry Podyplomowych Studiów Doskonalenia Katechetycznego.

\section{Konferencje naukowe}

Katedra Teologii Katolickiej w roku akademickim 2010/2011 zorganizowała lub współorganizowała następujące konferencje:

Organizacja samodzielna:

- 2011, (08. 01), „W komunii z Bogiem” - regionalna konferencja z udziałem katechetów;

- 2011, (01-02. 03), „Wybór drogi życiowej a sens życia: duszpasterstwo powołań" - warsztaty duszpasterskie dla księży; 
- 2011, (04. 06), „Dwudziestolecie wizyty Jana Pawła II w Białymstoku” konferencja ogólnopolska.

Współorganizacja:

- 2010, (07-09. 10), „Nuncjatura Apostolska w Rzeczpospolitej. Stan badań i perspektywy" - międzynarodowa konferencja naukowa zorganizowana w kooperacji z Zakładem Historii Nowożytnej UwB.

\section{Działalności naukowo-badawcza}

\section{ks. abp prof. dr hab. Edward Ozorowski}

Publikacje:

- Kapłan zawsze potrzebny, (kazanie z 1 października 2010), „Wiadomości Kościelne Archidiecezji Białostockiej”, 38 (2010), nr 2, s. 74-76;

- Trojaka tajemnica Wieczernika, (kazanie z 1 kwietnia 2010), tamże, s. 77-78;

- Czuwanie ożywiające, (kazanie z 3 kwietnia 2010), tamże, s. 79-81;

- Radość rezurekcyjna, (kazanie z 4 kwietnia 2010), tamże, s. 81-83;

- Tragedia, która daje do myślenia, (kazanie z 10 kwietnia 2010), tamże, s. 83-85;

- Wybitny Polak, (kazanie z 16 kwietnia 2010), tamże, s. 85-87;

- Wierzę w Ducha Świętego, „W Służbie Miłosierdzia”, 7 (2010), nr 5, s. 10;

- Pana i Ożywiciela, tamże, nr 6, s. 10;

- Który od Ojca i Syna pochodzi, tamże, nr 7, s. 10;

- Który z Ojcem i Synem wspólnie odbiera uwielbienie i chwałę, tamże, nr 8, s. 10 ;

- Który mówił przez proroków, „Drogi Miłosierdzia”, 1 (2010), nr 1, s. 16;

- Wierze w Kościół, tamże, nr 2, s. 16;

- Jeden Kościót, tamże, nr 3, s. 16;

- Słowo wstępne, [w:] M. Sopoćko, Dziennik, Białystok 2010, s. 5-6;

- Przynależność do Kościoła, „Drogi Miłosierdzia”, l (2010), nr 4, s. 16;

- W komunii z Bogiem, tamże, s. 16;

- Teologia ojcostwa, „Rocznik Teologii Katolickiej”, 9 (2010), s. 18-24;

- Promotorzy kultu Bożego Miłosierdzia, „Wiadomości Kościelne Archidiecezji Białostockiej", 38 (2010), nr 4, s. 61-65;

- Witaj, Królowo Matko Miłosierdzia, tamże, s. 65-69;

- W komunii z Bogiem, tamże, s. 70-72;

- Nic nas nie może odłaczyć od Miłości Chrystusowej, tamże, s. 72-73;

- Z Maryja w komunii z Bogiem, tamże, s. 158-159;

- Kościół Święty, „Drogi Miłosierdzia”, 2 (2011), nr l, s. 16;

- Uwikłania miłości małżeńskiej w „Annie Kareninie” Lwa Tołstoja, [w:] W stużbie Bogu bogatemu w Miłosierdzie, Olsztyn 2011, s. 150-160;

- Słowo wstępne, [w:] A. Dobroński, Harcerstwo w Białymstoku do 1939 r., Białystok 2011, s. 3; 
- Powszechny (katolicki), „Drogi Miłosierdzia” 2 (2011), nr 3, s. 16;

- Albo Bóg, albo nie, [w:] P. Murziński, New Age, czyli współczesna wieża Babel, Białystok 2011, s. 5-6;

- Kościoły partykularne, „Drogi Miłosierdzia”, 2 (2011), nr 4, s. 16;

- Teologia ojcostwa, [w:] Mężczyzna - etyka - ekonomia, Białystok 2011, s. 11-17;

- Korzenie zła, [w:] A. Proniewski, Kim on jest? Hermeneutyka demonologii, Białystok 2011, s. 9;

- Pamięć uobecniająca, [w:] M. Kietliński, A. Szot, Błogosławiony wśród nas, Białystok 2011, s. 6;

- List zokazji dwudziestej rocznicy pobytu Jana Pawła II w Białymstoku, „Drogi Miłosierdzia", 2 (2011), nr 6, s. 3;

- Apostolski, tamże, s. 16;

- Kościoły lokalne w Kościele powszechnym, [w:] Parafia w Kalinówce Kościelnej 1511-2011, red. A. Szot, Białystok 2011, s. 7.

Udział w konferencjach:

- 2010, (07-09.10), Białystok, międzynarodowa konferencja naukowa: Nuncjatura Apostolska w Rzeczypospolitej. Stan badań i perspektywy, współorganizacja;

- 2011, (08. 01), Białystok, konferencja naukowa: W komunii z Bogiem, organizacja;

- 2011, (01-02.03), Białystok, warsztaty duszpasterskie dla księży: Wybór drogi życiowej a sens życia: duszpasterstwo powołań, organizacja;

- 2011,(04. 06), Białystok, konferencja naukowa: Dwudziestolecie wizyty Jana Pawła II w Białymstoku, organizacja.

\section{ks. prof. dr hab. Józef Zabielski}

Publikacje:

- Współred. Życie człowieka jako zobowiazujący dar, red. A. Skreczko, J. Zabielski, Białystok 2011;

- Misja Kościoła wobec dominacji mass mediów w świecie, [w:] Kościół a Europa w dobie wspótczesnej, red. M. Olszewski, E. Kirstukas, Wilno 2010, s. 127-148;

- Religijno-moralne wartościowanie życia i śmierci jako duchowe bezpieczeństwo starzejącego się człowieka, [w:] Zagrożenia w starości i na jej przedpolu, red. M. Halicka, J. Halicki, K. Czykier, Białystok 2010, s. 19-31;

- Рэлятывізм як дэфармацыя грамадска - маральнага жыіция, [w:] Религия и общество - 5: актуальны іе проблемы свободы совести, red. В. В. Смаросменко, О. В. Дьяченко, Могилев 2010, s. 120-123;

- Aretologiczne „umocowanie” życia społeczno-moralnego, „Rocznik Teologii Katolickiej", 9 (2010), s. 64-78;

- Korupcja jako problem i wyzwanie współczesnej administracji, „Studia Socialia Cracoviensia", 1 (2010), nr 2, s. 37-48; 
- Rodzina jako środowisko rozwoju religijno moralnego w nauczaniu Kardynała Stefana Wyszyńskiego, „Studia Prymasowskie”, 4 (2010), s. 283-294;

- Integralny rozwój ludzkości według encykliki Benedykta XVI Caritas in Veritate, „Collectanea Theologica”, 80 (2010), nr 3, s. 105-113;

- Aksjologiczne podstawy życia społecznego, Teologia i moralność, t. 8, Poznań 2010, s. 65-81;

- Wspólnototwórcza rola mężczyzny, [w:] Mężczyzna - etyka-ekonomia, red. E. Ozorowski, R. Horodeński, Białystok 2011, s. 19-31;

- Normatyw godności osoby niepełnosprawnej, [w:] Życie człowieka jako zobowiazujący dar", red. A. Skreczko, J. Zabielski, Białystok 2011, s. 274-285;

- Wstęp, [w:] Życie człowieka jako zobowiązujący dar, red. A. Skreczko, J. Zabielski, Białystok 2011, s. 7-10;

- Kalinowskie środowisko wzrastania w powołaniu, [w:] Parafia w Kalinówce Kościelnej 1511-2011. Pięć wieków historii, red. A. Szot, Białystok 2011, s. 65-75;

- Przemoc w rodzinie jako destrukcja relacji osobowych, „Sosnowieckie Studia Teologiczne", 10 (2011), s. 267-281;

- Rec. Bp A. Dziuba, Kardynat Stefan Wyszyński, Kraków 2010, „Studia Prymasowskie", 4 (2010), s. 330-332;

- Rec. J. Gniadek, Dwaj ludzie z Galicji. Koncepcja osoby ludzkiej według Ludwiga von Misesa i Karola Wojtyły, Warszawa 2011, „Nurt SVD“, 44 (2010), z. 2, s. 339-345.

Udział w konferencjach:

- 2010, (6-7. 09), Supraśl, konferencja naukowa: „Działalność patriotyczna kobiet z perspektywy XXI wieku”, referat: „Aksjologiczna aktualność «Matki-Polki» w świecie postnowoczesnym";

- 2010, (13-16. 09), Poznań, Kongres Teologów Polskich: „Między sensem a bezsensem ludzkiej egzystencji. Teologiczna odpowiedź na fundamentalne pytania współczesnego człowieka”, uczestnictwo, udział w dyskusji;

- 2010, (06. 12), Warszawa, konferencja: „Ewangelia życia dzisiaj. Recepcja encykliki Evangelium vitae po 15 latach", uczestnictwo, udział w dyskusji;

- 2011, (10-13. 03), Białystok, VI Międzynarodowa Konferencja Naukowo-Szkoleniowa: „Życiodajna śmierć - pamięci Elisabeth Kübler-Ross” (VI International Scientific-Educational Conference „Life-Giving Death - In Memory of Elisabeth Kübler-Ross”)”, referat: „Norma personalistyczna jako aksjologiczny imperatyw bioetyki";

- 2011, (24. 03), Białystok, Narodowy Dzień Życia, referat: „Sztuczna prokreacja jako deformacja prawdy o człowieku";

- 2011, (09. 05), Warszawa, konferencja: „Theosis horyzontem życia chrześcijańskiego", uczestnictwo, przewodniczenie konferencji; 
- 2011, (04.06), Białystok, sesja popularnonaukowa: „Dwudziestolecie wizyty Jana Pawła II w Białymstoku”, uczestnictwo, prowadzenie sesji;

- 2011, (12-14.06), Warszawa, Ogólnopolskie Spotkanie Naukowe Stowarzyszenia Teologów Moralistów: „Strategie argumentacyjne w chrześcijańskiej bioetyce", uczestnictwo, prowadzenie sesji.

\section{ks. dr hab. Adam Skreczko prof. UwB}

Publikacje:

- Współred. Życie jako zobowiązujący dar, red. A. Skreczko, J. Zabielski, Białystok 2011, ss. 235;

- Wybrane przejawy troski Kościoła katolickiego o rodzinę w Polsce, „Studia nad Rodziną", 13 (2009) nr 1-2, s. 129-148;

- Rola Kościoła w przezwyciężaniu manipulacji w mediach, „Studia Teologiczne. Białystok-Drohiczyn-Łomża”, 28 (2010), s. 237-254;

- Ojcostwo jako zadanie, „Rocznik Teologii Katolickiej”, 9 (2010), s. 25-38;

- Aktueller Stand der Pastoraltheologie in Polen, „International Journal of Practical Theology", 14 (2010), s. 259-272;

- Wyzwania pastoralne stojące przed Kościołem katolickim związane z cielesnościa człowieka, [w:] Stworzeni do miłości, red. J. A. Najda, Warszawa 2011, s. 57-63;

- Mężczyzna jako wychowawca, [w:] Mężczyzna - etyka - ekonomia, red. R. Horodeński, E. Ozorowski, Białystok 2011, s. 33-41;

- Wiara, nadzieja, miłość warunkiem budowania lepszej przyszłości, [w:] Wojewódzki Sejmik Aksjologiczny Podlaskiej Rodziny Szkół imienia Bohaterów Walki o Niepodległość Rzeczypospolitej, red. B. Szypulska, Korycin 2011, s. 14-17;

- Rodzicielskie poszanowanie życia, [w:] Życie jako zobowiązujący dar, red. A. Skreczko, J. Zabielski, Białystok 2011, s. 205-220;

- Rodzina jako pierwsza szkoła życia społecznego, [w:] Aspekty wychowania dziecka $w$ rodzinie, red. J. Kułaczkowski, Warszawa 2010, s. 31-57;

- Rec. Józef Zabielski, Teologiczno-etyczne podstawy ładu społecznego, Wydawnictwo Uniwersytetu w Białymstoku, Białystok 2010, ss. 268, „Rocznik Teologii Katolickiej”, 9 (2010), s. 276-278;

- Przemówienie rektora AWSD w Białymstoku z okazji inauguracji roku akademickiego 2010/2011, „Wiadomości Kościelne Archidiecezji Białostockiej”, 38 (2010), nr 3, s. 88-94;

- Kapłan o pogodnym usposobieniu, [w:] Kapłan mądry sercem, red. E. Młyńska, Białystok 2010, s. 302-303;

- Bariery w rozmowie rodzica $z$ dzieckiem, „Drogi Miłosierdzia”, 3 (2011) nr 7, s. 17; 
- Najświętsza Maryja Panna Matka Pięknej Miłości, „Wiadomości Kościelne Archidiecezji Białostockiej”, 1 (2010), nr 4, s. 177-180;

- Konstruktywne pochwały, „Drogi Miłosierdzia”, 2 (2011), nr 6, s. 15;

- Biblia w wychowaniu rodzinnym, „Drogi Miłosierdzia”, 2 (2011), nr 7, s. 21;

- Język religijny $w$ domu, „Drogi Miłosierdzia”, 2 (2011), nr 8, s. 21;

- Rola matki w wychowaniu, „Drogi Miłosierdzia”, 2 (2011), nr 9, s. 21;

- Konstruktywne pochwały, „Drogi Miłosierdzia”, 2 (2011), nr 10, s. 21.

Udział w konferencjach:

- 2010, (6-7. 09), Supraśl, ogólnopolska konferencja naukowa: „Działalność patriotyczna kobiet z perspektywy XXI wieku”, referat: „Marcelina Darowska - nauczycielka patriotyzmu podczas zaborów";

- 2010, (13-15. 09), Płock, XLVI Zjazd Rektorów Wyższych Seminariów Duchownych: „Formacja alumnów do wspólnoty teraz i w przyszłości”, udział;

- 2010, (19. 09), Bratysława (Słowacja), międzynarodowa konferencja naukowa: „Rodina v sučasnom svete. L'udska zrelost' a stabilita malželstva a rodiny” („Rodzina we współczesnym świecie. Dojrzałość ludzka a trwałość małżeństwa i rodziny”), referat: „Rola Kościoła w kształtowaniu dojrzałości ludzkiej małżonków i rodziców. Aspekt pastoralny";

- 2010, (29. 09), Korycin, I Wojewódzki Sejmik Aksjologiczny Podlaskiej Rodziny Szkół im. Bohaterów Walki o Niepodległość Rzeczypospolitej, referat: „Wiara, nadzieja, miłość - warunkiem budowania lepszej przyszłości”;

- 2010, (08. 12), Sokółka, VI Zjazd Podlaskiej Rodziny Szkół im. Jana Pawła II, udział;

- 2011, (08. 01), Białystok, konferencja naukowa: „W komunii z Bogiem”, organizacja i prowadzenie;

- 2011, (10-13. 03), VI międzynarodowa konferencja naukowo-szkoleniowa: „Bioetyka i wielokulturowość w medycynie”, referat: „Eutanazja jako fałszywe miłosierdzie";

- 2011,(14.05), Łomianki, konferencja naukowa: „Rodzina wspólnotą pokoleń i gwarantem dziedzictwa tradycji”, referat: „Rodzina przekazicielem kultury chrześcijańskiej";

- 2011, (12. 05), Drohiczyn, zjazd profesorów seminariów duchownych z Białegostoku, Drohiczyna, Łomży, Siedlec i Ełku: „Małżeństwa mieszane wyznaniowo-ekumeniczna szansa i życiowe problemy", udział;

- 2011, (26-27. 05), Ołtarzew, sympozjum naukowe: „Apostolat Ludu Bożego w nauczaniu Stefana Kardynała Wyszyńskiego”, referat: „Małżeństwo i rodzina w urzeczywistnieniu programu Wielkiej Nowenny przed Tysiącleciem Chrztu Polski - inspiracje Kardynała Wyszyńskiego". 


\section{ks. dr Tadeusz Kasabuła}

Publikacje:

- Pac Kazimierz, [w:] Encyklopedia Katolicka, t. 14, Lublin 2010, kol. 1076-1077;

- Pac Mikołaj, [w:] Encyklopedia Katolicka, t. 14, Lublin 2010, kol. 1077;

- Pac Mikołaj Stefan, [w:] Encyklopedia Katolicka, t. 14, Lublin 2010, kol. 1077-1078;

- Pancerzyński Karol Piotr, [w:] Encyklopedia Katolicka, t. 14, Lublin 2010, kol. 1203;

- Parczewski Piotr, [w:] Encyklopedia Katolicka, t. 14, Lublin 2010, kol. 1350-1351;

- Misje wśród Słowian południowych jako narzędzie rywalizacji między Wschodem a Zachodem, [w:] Chrześcijańskie dziedzictwo duchowe narodów słowiańskich, seria II: Wokót kultur śródziemnomorskich, t. 2: Historia, język, kultura, red. Z. Abramowicz, J. Lawski, Białystok 2010, s. 315-323;

- Pozycja społeczna mężczyzny na ziemiach polskich w XIX wieku, [w:] Mężczyzna-Etyka-Ekonomia, red. E. Ozorowski, R. Horodeński, Białystok 2010, s. 81-88;

- Rec.: Lietuvos istorijos šaltiniai, t. VII, Breslaujos dekanato vizitacija 17821783 m. atlikta vilniaus vyskupo Ignoto Jokūbo Masalskio parédymu, oprac. Romualdas Firkovičius, Lietuvių Katalikų Mokslo Akademija, Vilnius 2008, ss. 452+XI (Źródła do dziejów Litwy, t. VII, Wizytacja dekanatu brasławskiego 1782-1783 r. przeprowadzona na polecenie biskupa wileńskiego Ignacego Jakuba Massalskiego, oprac. Romualdas Firkovičius, Litewska Katolicka Akademia Nauk, Wilno 2008, ss. 452+XI) „Rocznik Teologii Katolickiej”, 9 (2010), ss. 271-275;

- Sprawozdanie z działalności Międzywydziałowej Katedry Teologii Katolickiej Uniwersytetu w Bialymstoku w roku akademickim 2008/2009, „Rocznik Teologii Katolickiej”, 9 (2010), ss. 233-239;

- Paweł Holszański, Algimund [w:] Encyklopedia Katolicka, t. 15, Lublin 2011, kol. 134;

- Pietkiewicz Jerzy, [w:] Encyklopedia Katolicka, t. 15, Lublin 2011, kol. 543-544;

- Piotr, Piotr de Warta bp, [w:] Encyklopedia Katolicka, t. 15, Lublin 2011, kol. 659-660;

- Plichta Jakub OFM, bp, [w:] Encyklopedia Katolicka, t. 15, Lublin 2011, kol. 819;

- Poczobut Marcin SJ, [w:] Encyklopedia Katolicka, t. 15, Lublin 2011, kol. 920-921 (współautor. z A. P. Bieś);

- Pohl Andrzej CM, [w:] Encyklopedia Katolicka, t. 15, Lublin 2011, kol. 1002-1003;

- Połubiński Jerzy Antoni bp, [w:] Encyklopedia Katolicka, t. 15, Lublin 2011, kol. 1352; 
- Zaangażowanie religijne wiernych parafii Goniadz w okresie przedrozbiorowym, [w:] Małe Miasta. Społeczność, red. M. Zemło, Lublin - Supraśl 2011, s. 161-171.

Udział w konferencjach:

- 2010, (7-9. 10), międzynarodowa konferencja naukowa: „Nuncjatura Apostolska w Rzeczypospolitej. Stan badań i perspektywy”, współorganizacja;

- 2011, (12-14. 05), Białystok, międzynarodowa konferencja naukowa: „Pogranicza, Kresy. Wschód a idee Europy”, referat: „Wpływ Wschodu na kulturę życia codziennego szlachty polskiej w okresie przedrozbiorowym";

- 2011,(04. 06), Białystok, sesja popularnonaukowa: „Dwudziestolecie wizyty Jana Pawła II w Białymstoku”, współorganizacja;

- 2011, (30.09), Lublin, sympozjum: „Księgi wizytacyjne w archiwalnych zasobach kościelnych. Dawniej i dzis'”, referat: „Wartość źródłowa akt wizytacji diecezji wileńskiej z II połowy XVIII wieku”.

\section{ks. dr Andrzej Proniewski}

Publikacje:

- Kim on jest? Hermeneutyka demonologii, Białystok 2011, ss. 136;

- Ojcostwo fizyczne i duchowe, [w:] Mężczyzna - etyka - ekonomia, red. E. Ozorowski, R. Horodeński, Białystok 2011, s. 51-62;

- Hermeneutyka teologii życia, [w:] Życie człowieka jako zobowiązujący dar, red. A. Skreczko, J. Zabielski, Białystok 2011, s. 258-273.

Udział w konferencjach:

- 2010, (07-09. 09), Białystok, międzynarodowa konferencja naukowa: „Nuncjatura Apostolska w Rzeczypospolitej. Stan badań i perspektywy”, współorganizacja

- 2011, (08. 01), Białystok, konferencja naukowa: „W komunii z Bogiem”, współorganizacja;

- 2011, (28. 04), Białystok, konferencja: „Twój Przyjaciel Streetworker”, organizacja;

- 2011,(01-02.03), Białystok, warsztaty duszpasterskie dla księży archidiecezji białostockiej: „Duszpasterstwo powołań”, współorganizacja;

- 2011, (09-20. 05), Białystok, IX Podlaski Festiwal Nauki i Sztuki, referat: „W nurcie nauczania Benedykta XVI”, współorganizacja;

- 2011,(04. 06), Białystok, sesja popularnonaukowa: „Dwudziestolecie wizyty Jana Pawła II w Białymstoku”, współorganizacja.

Dorobek naukowy Katedry Teologii Katolickiej w roku akademickim 2010/2011 to zorganizowane 3 konferencje krajowe i 1 międzynarodowa, 1 monografia, 10 publikacji $\mathrm{w}$ recenzowanych czasopismach krajowych i zagranicznych, 13 tekstów stanowiących rozdziały w opracowaniach monograficznych i 3 publikacje 
o charakterze monografii wieloautorskiej. Ogółem stanowi to 45 publikacji punktowanych dających 154 punkty. Dorobek piśmienniczy pracowników Katedry uzupełnia pokaźna liczba artykułów, recenzji, wydawnictw materiałów źródłowych i tekstów popularnonaukowych niepunktowanych, a publikowanych w czasopismach o zakresie głównie lokalnym, popularyzujących nauki teologiczne, filozoficzne i historyczne $\mathrm{w}$ regionie.

ks. Tadeusz Kasabuła Uniwersytet w Białymstoku 